Portland State University

PDXScholar

5-18-1973

\title{
A Descriptive Analysis of a Metropolitan Foster Parent Population as an Indicator for Recruitment
}

\author{
Elizabeth Connet \\ Portland State University \\ Judy Fretta \\ Portland State University \\ Rodney Harry \\ Portland State University \\ Rosemarie Orange \\ Portland State University \\ Nancy Simmons \\ Portland State University
}

Follow this and additional works at: https://pdxscholar.library.pdx.edu/open_access_etds

Part of the Social Work Commons

Let us know how access to this document benefits you.

\section{Recommended Citation}

Connet, Elizabeth; Fretta, Judy; Harry, Rodney; Orange, Rosemarie; and Simmons, Nancy, "A Descriptive Analysis of a Metropolitan Foster Parent Population as an Indicator for Recruitment" (1973). Dissertations and Theses. Paper 1770.

https://doi.org/10.15760/etd.1769

This Thesis is brought to you for free and open access. It has been accepted for inclusion in Dissertations and Theses by an authorized administrator of PDXScholar. Please contact us if we can make this document more accessible: pdxscholar@pdx.edu. 
A DESCRIPTIVE ANALYSIS OF A METROPOLITAN FOSTER PARENT POPULATION AS AN INDICATOR FOR RECRUITMENT

\author{
by \\ EIIZABETH CONNET \\ JUDY FRETTA \\ RODNEY HARRY \\ ROSEMARIE ORAINGE \\ NANCY SIMMONS
}

A group practicum submitted in partial fulfillment of the requirements for the degree of

MASTER OF SOCIAL WORK

Portland State University

1973 
TO THE OFFICE OF GRADUATE STUDIES :

The members of the Committee approve the practicum

of Elizabeth Connet, et al. presented $5 / 18 / 73$

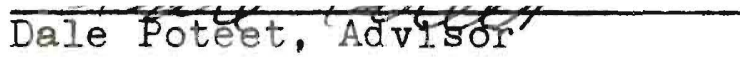

Eward P. Smith, Advisor

\section{APPROVED :}

Gordon Hearn, Dean, School of Social Work May, 1973 
A DESCRIPTIVE ANALYSIS OF A METROPOIITAN FOSTER PARENT POPUIATION AS AN INDICATOR FOR RECRUITMENT

\section{Foreword:}

"...research takes longer, costs more, and finds out less than one had hoped."

Polansky's Law

Introduction:

Recruiting and retaining a sufficient number of foster homes to offer quality care of children is of prime importance in the delivery of Child Welfare services. There are an insufficient number of foster homes available for the appropriate placement of foster children in Multnomah County, Oregon according to the largest placement agency in Oregon, Children's Services Division. The Tri-County Foster Parent's Association signed a Purchase of Service Agreement with the Oregon Children's Services Division to develop a recruitment program to obtain additional foster homes. In an effort to do this effectively, the Foster Parent Association asked Portland State University School of Social Work to do a

INorman A. Polansky, Robert D. Borgman, and Christine De. Saix, Roots of Futility (San Francisco, 1972) p. xi. 
descriptive analysis of the Multnomah County* foster parent population. The Association wished to determine if there were measureable characteristics of certified foster parents which could be used as indicators for recruitment. The purpose of the study was to collect pertinent information, retrieve and analyze it, and report to the Foster Parent Association.

\section{REVIEW OF LITERATURE:}

Previous studies of foster care have analyzed the attitudes and motivations of foster parents. These are well summarized in "Foster Parenting: An Integrative Review of the Iiterature" by Taylor and Starr (1967).2 Recruitment problems, foster parent selection, and the caseworker-foster parent relationship have also been given attention by researchers. 3 Foster care failures have received much attention. However, little has been determined about the total population of foster families in larger communities. Only two major studies (Fanshel,

* Nultnomah County contains the largest metropolitan area in Oregon and has a population of over a half million people.

2Delores A. Taylor and Phyllis Starr, "Foster Parenting: An Integrative Review of the Literature," Child Welfare, XIVI (July, I967), pp. 37l-385.

3David Fanshel, "Foster Parenthood: A Role Analysis (Minneapolis, 1966). 
Foster Parenthood: A Role Analysis, 4 and Kraus, Predicting Success of Foster Placements for School-Age Children ${ }^{5}$ ) have integrated data of over a hundred families to develop a comprehensive picture of foster care in a particular community. Fanshel's study collected in-depth data from only six families, and the general data has relevance mainly to industrial, coal mining communities similar to the Pittsburg area. Kraus studied 157 families in New Zealand, to determine what data, if any, would predict successful child placement. While he found no independently statistically significant factors, he did identify clusters of factors that indicated probable successful placements.

Five studies made between 1950 and 1969 dealt with children in long-term or permanent foster care; all five together studied less than 1000 children. Over 900 of the children were placed from 10-30 years ago, when placement practice and socio-economic climate were different from the present time. ${ }^{6}$ These studies do not provide the

4 Ibid.

5 Jonathan Kraus, "Predicting Success of Foster Piacements for School-Age Children," Social Work, 16 (January, 1971), p. 63.

6Bernice Madison and Michael Shapiro, "Permanent and Long-Term Foster Family Care as a Planned Service," Child Welfare, XLIV (March, 1970), pp. 131-166. 
Information needed for current placement, recruitment and analysis. There were no studies found which dealt with the difficulties of retrieving data from large agencies.

\section{Methodology:}

The original plan was to obtain relevant data from the State of Oregon Foster Parent Report (form FH 1003) which was designed for research purposes and the certification process. The following information is recorded on this form: names of foster parents, address including zip codes, birth years, race, religion, employment status, number of children in home related to foster parents, number of children not related, number of other adults in the household, source of referral, location of home (size of community), approximate income, the number, sex, and ages of foster children for which the home is certified. As the state office was unable to provide these forms, the following methods were employed.

All information in this research was taken from the State of Oregon payment list of certified foster homes, Multnomah County Children's Services Division list of active homes, and the Multnomah County current foster home cards. Included were foster homes actually caring for children at the time of this study as well as those certified but having no children placed in the home.

The CSD list of active homes was compiled by the 
Multnomah county office. It included the foster home number, foster family name, address, zip code, race, religion, and children desired. The payment list was furnished. by the state office and it indicated active homes for the month of April, 1972. This list included name, address, and zip code of the foster parent.

All current foster parent cards (MPW 129) were duplicated. These represented the major source of the information gathered. These included the case number, foster home number, foster family name, address, phone number, birth dates, others in the household, dates of certification and renewal, race, religion, school area, certification terms or preference, names of foster children placed in the home, their birth dates, caseworkers, rates of payment, and dates children were placed and removed from the foster home.

After this information was gathered, a comprehensive Iist was developed as of June 1, 1972. A sub-Iist was drawn to indicate those homes certified for two years or more and those homes certified for less than two years. The two-year period from June, 1970 to June, 1972 was selected as the basis for this research.* After this process was completed, information from

*This was done by utilizing the foster home certification number 8543 issued by the State of Oregon, June 1 . 1970 as the beginning number. 
the cards significant to the study was tabulated in different categories: foster home number, zip code, parentage (one-parent or two-parent homes), race, religion, vacancy periods, length of stay in home, certification date, total number of foster children placed in the home, number of foster children presently in home, certification preference, number of caseworkers, age of foster parents, and number of natural children in the home and their ages. All of this data was punched on IBM cards. A computer program was developed and used to organize the material in this research. Random samples were developed to verify the results of the computer data.

Results and Implications:

According to the results, $33 \%$ of the homes were located in the Model Cities and Northeast Districts, $11 \%$ in Southeast, $11 \%$ in East Multnomah, and $16 \%$ in West District. Two percent of the foster homes were located in adjacent counties. The other $27 \%$ of the homes had zip codes which were not in use in the area. The recent division of Multnomah County into districts by the Children's Services Division makes knowing the location of foster homes important. Ordinarily an attempt is made to place children in their own communities. Therefore, recruitment needs to be concentrated in those districts with the largest number of children requiring care outside of their owr. homes. 
The amount of error in this portion of the study is so great that the percentages are unreliable. The reascins for this are not known; it may have been a combination of incorrect zip codes on the foster parent cards or on the foster parent lists, incorrect coding for the computer, or punching errors. (T'he FH 1003 form would have had accurate zip codes.) The information compiled is of little or limited use for recruitment as a result of the number of errors.

of the 1034 certified homes in June, 1972, $89 \%$ were two-parent families, 10\% were one-parent families headed by women, and $1 \%$ were one-parent families headed by men.

The parents in $84 \%$ of the homes in the study were White, $13 \%$ were $\mathrm{Black}$, and the remaining $3 \%$ of the parents were mixed combinations of Black, White, Oriental or Indian.

On the foster home cards, the religious preference of $27 \%$ of the foster parents was listed as Protestants and $14 \%$ as Catholic. No religous preference was indicated for $6 \%$. Thirteen percent were 1dentified as Baptist, $9 \%$ Luthereran, $31 \%$ were distributed among twelve other denominations. There was no indication as to whether the foster parents were active or inactive church members.

It was speculated that a correlation between the number of children placed with the vacancy periods and length of child placement in the home would measure 
adequacy of care. Results indicated that $69 \%$ of the homes had had from one to five children placed in two years, $12 \%$ six to ten children, $10 \%$ eleven to twenty, and $9 \%$ had more than twenty children placed. Thirty percent of the homes had no vacancles. Forty-seven percent of the homes were vacant less than three months, $8 \%$ 4-6 months, $11 \%$ 7-12 months, and $4 \%$ for more than twelve months. There were 2,890 placements during the two-year period. Twenty-four percent of the children were placed from one to thirty days, $43 \%$ from one to six months, and $33 \%$ from seven months to two years or more.

Although the percentages are statistically reliabie, they are not valid for indicating the effectiveness of the homes in terms of child care. To establish validity, additional information would be required as to whether or not the length of stay corresponded to the needs of the child, whether or not the caseworker found it necessary to remove the child, or whether or not the foster parents asked to have the child moved. According to Jonathan Kraus, a foster home is only successful if a child is able to remain in the home for the period of time he must be away from his natural family.*

\footnotetext{
see the Kraus article previously cited.
}

*For discussion of criteria of success of placement, 
In terms of this study, foster homes which have been certified for a two-year or longer period indicate success in staying with the foster home program. The results of the study show that $53 \%$ of the homes had been certified for more than one year and $47 \%$ for less than a year. Of the $53 \%$, $6 \%$ were certified for over one year, $7 \%$ for two years, $10 \%$ for three years, $16 \%$ for four years, and $14 \%$ for over five years or more.

According to the foster home cards, homes were certifled for the following age ranges:

PERCENTAGE OF FOSTER HOMES CERTIFIED BY AGE RANGE OF CHILDREN

\begin{tabular}{|rccc|}
\hline $13 \%$ & were certified for & $0-5$ & year category \\
$21 \%$ & $"$ & $0-18$ & $"$ \\
$7 \%$ & $"$ & $6-13$ & $"$ \\
$14 \%$ & $"$ & $0-13$ & $"$ \\
$3 \%$ & $"$ & $14-18$ & $"$ \\
$30 \%$ & $"$ & specific children \\
$3 \%$ & of the cards had no information \\
\hline
\end{tabular}

An attempt was made to find out how many foster children were in each home in June, 1972, categorized by age and sex. A similar effort was made to record the number, sex, and age of natural children in the home. (This information was requested by the Foster Parent Association.) It was not possible for the material on the foster children to be computerized. within the time span avai.able and the information on the cards concerning natural children was not up-to-date. 
An attempt was made to tally the ages of foster parents. Errors in transpostion of material, punching, or programming made age determination impossible. Ages of foster parents would have had to be correlated with retention of foster homes to be of significance for recruitment.

The number of caseworkers directly involved with the foster family may have a definite bearing on the retention of foster homes by Children's Services Division. The foster home cards were the only source for this information and the information on the cards was not reliable. When caseworkers were changed, the original name was erased and the current worker's name was written in so that the total number of caseworkers was not obtainable.

A correlation between children desired by foster parents according to number, sex, and age and the actual children placed was attempted. This correlation was unobtainable because the information on the foster parent card with regard to preference was not current. Foster home cards indicate the original terms of certification; changes effected at the time of annual recertification are not consistently recorded. If the foster home report (FH 1003) had been avallable, it would have been possible to determine if the foster children in the home were matched to the current terms of the certificate. 


\section{Conclusions:}

The study revealed data with regard to the number of certified homes as of June, 1972, percentages of two-parent and one-parent homes, religious preference, race, number of children placed within a two-year time span, vacancy periods and length of placements.

The research findings did not indicate which geographical areas were important for recruitment. Ages, sex, and numbers of foster children were on the foster home card, but terms of the certificate were not current; determination of matching child desired with child placed was impossible. The number of natural children in the homes was not recorded accurately or currently and therefore was not useable. There was no indication whether a home had been in continuous certification from date of original application or whether it had been closed and reopened.

It was the conclusion of the researchers that an accurate system for recording, compling and analyzing foster parent characteristics does not exist. The foster parent report form (FH 1003) was not avallable; we could not obtain information about employment, number of natural children in home, number of unrelated children in home, or ápproximate income. Accurate information about zip codes and terms of the certificate were not 
available. Because some of the data is incomplete, some is out-of-date, some not available, a descriptive analysis could not be done.

It is the recommendation of the research team that all foster care placement agencies make provision for accurate records so that the information is readily available and retrieveable for research purposes.

\section{Suggestions for Future Research:}

1. Determine if there is a correlation between age of foster parents and retention of the foster home in the program.

2. Determine if there is a correlation between length of child placement and adequacy in terms of the child's needs.

3. Determine if retention in the foster home program indicates success of the home in terms of the child's needs.

4. Determine the percentage of successful "specific child only" homes.

5. Determine numbers of "specific child only" homes that later convert to regular foster home care. 


\section{BIBLIOGRAPHY}

Fanshel, David. Foster Parenthood: A Role Analysis. Minneapolis, 1966.

Kraus, Jonathan. "Predicting Success of Foster Placements for School-Age Children," Social Work, 16 (January, 1971).

Madison, Bernice, and Michael Shapiro. "Permanent and Long-Term Foster Family Care as a Planned Service," Child Welfare, XLIX, (March, 1970).

Polansky, Norman A., Robert D. Borgman, and Christine De Saix. Roots of Futility. San Francisco, 1972.

Taylor, Delores A., and Phyllis Starr. "Foster Parenting. An Integrative Review of the Literature," Child Welfare, XVII, (July, 1967). 